Saudi Journal of Oral and Dental Research

Abbreviated Key Title: Saudi J Oral Dent Res

ISSN 2518-1300 (Print) |ISSN 2518-1297 (Online)

Scholars Middle East Publishers, Dubai, United Arab Emirates

Journal homepage: https://saudijournals.com/sjodr

\title{
Surgical Audit of Major Oral and Maxillofacial Cases in a Tertiary Hospital in South-South Nigeria - A 5-year Retrospective Review
} Okoro N. N ${ }^{1}$, Egbor P. $\mathrm{E}^{2^{*}}$

\begin{abstract}
${ }^{1}$ BDS, Senior Registrar, Department of Oral and Maxillofacial Surgery, University of Benin Teaching Hospital, PMB 1111, Benin Lagos Express Road, Uselu 300283, Benin City, Nigeria

${ }^{2}$ BDS, FWACS, Consultant Oral and Maxillofacial Surgeon, Department of Oral and Maxillofacial Surgery, University of Benin Teaching Hospital, PMB 1111, Benin Lagos Express Road, Uselu 300283, Benin City, Nigeria
\end{abstract}

DOI: $10.36348 /$ sjodr.2021.v06i01.004

| Received: 18.03.2020 | Accepted: 25.03.2020 | Published: 09.01.2021

*Corresponding author: Egbor P. E

\section{Abstract}

The aim of this study is to an audit of the types, patterns, and indications for major oral and maxillofacial surgeries carried out at the Department of Oral and Maxillofacial Surgery, University of Benin Teaching Hospital from January 2015 to December 2019. The findings from this study should provide valuable information to develop a future strategic plan, and improve clinical care. A retrospective review of the hospital records (including theatre logbooks, theatre lists, case notes and admission notebooks in the wards) of all patients operated upon within the study period was done. Descriptive statistics were used to analyze the collected data. Two hundred and forty-two (242) patients who had two hundred and eighty-eight (288) maxillofacial surgeries in the period under review formed the population for this study. There were $180(62.5 \%)$ males and $108(37.5 \%)$ females giving a male to female ratio of 1.6: 1 . The ages observed ranged from 3 months to 85 years (median age of 23 years and mean age of $22.36 \pm 20.09$ ). Congenital/developmental conditions formed the largest indication for surgery, accounting for $113(39.4 \%)$ of the cases seen. The most commonly performed surgery was cleft lip/palate repair $(36.1 \%, \mathrm{n}=104)$, followed by mandibulectomy and reconstruction using plating systems $(16.7 \%, \mathrm{n}=48)$. Major Oral and Maxillofacial surgeries are commonly carried out in our centre. The quality of service delivery can be improved upon through adequate manpower training in microvascular surgeries to help in better patient rehabilitation and provision of needed facilities.

Keywords: Surgical audit, oral and maxillofacial surgery.

Copyright (C) 2021 The Author(s): This is an open-access article distributed under the terms of the Creative Commons Attribution 4.0 International License (CC BY-NC 4.0) which permits unrestricted use, distribution, and reproduction in any medium for non-commercial use provided the original author and source are credited.

\section{INTRODUCTION}

Globally, the field of oral and maxillofacial surgery evolved over time as a result of the need to offer care to personnel injured in World War II. Years after the war, the specialty of oral and maxillofacial surgery has continued to flourish and become a wellestablished surgical subspecialty. The specialty is involved in a wide range of diseases of the mouth, jaws, and facial conditions. The scope of the specialty includes orofacial infections, facial trauma, oncology, implantology, salivary gland diseases, temporomandibular joint disorders, aesthetic surgeries, orofacial pain, cleft lip, and palate as well as other facial congenital and acquired deformities among others $[1,2]$.

In modern health care systems, there is a growing emphasis on monitoring the outcomes of a health intervention in general and surgical procedures in particular. This is often referred to as surgical audit in the United Kingdom or the surgeon's profiling in the United States of America. Surgical auditing is a systematic quality improvement process that seeks to improve patients' care and outcomes through a systematic review of care against explicit criteria and where indicated, changes are implemented and further monitoring is used to confirm improvement in the health care delivery system [3]. Surgical audit plays a very important role in policy formulation, research, improvement in service delivery, teaching and mentoring while also enabling prioritization and proper allocation and distribution of limited resources, especially in resource-limited countries [4, 5]. Various types of audit exist; national, regional, local as well as hospital-based audits. These are aimed at providing improved quality of care, provide continuous learning opportunities and guide appropriate use of resources. 
Okoro N. N \& Egbor P. E; Saudi J Oral Dent Res, Jan 2021; 6(1): 22-28

As the specialty continues to evolve, and the demand on the available resources increases, the need to continually evaluate the current health system in order to improve its effectiveness and efficiency becomes imperative [4]. To this end, a retrospective review of the major surgical cases is one of the ways of ensuring optimal or improved service provision $[6,7]$.

In Nigeria, there have been few reports of audits of oral and maxillofacial surgeries [6-8]. According to Ajike et al., [8], 78\% of the total patients seen at the Aminu Kano Teaching Hospital, Kano, Nigeria had maxillofacial surgical diseases. They stated that trauma accounted for the majority of the maxillofacial surgical conditions with tumour and tumour-like lesions accounting for less than $21 \%$ of cases. Ibikunle et al., [6] in a 5 years audit of major oral and maxillofacial surgical cases at the Usman Dan Fodio University Teaching Hospital, Sokoto, Nigeria, reported a wide range of oral and maxillofacial surgeries especially those bordering on tumour ablations. They recommended that with the observed relative frequency of tumour ablative surgeries, efforts should be intensified at prevention and post-surgical rehabilitation. They also opined that improved access to advance reconstructive techniques such as microvascular surgery be enhanced. It is however worthy of note that in the only study on the audit of maxillofacial surgeries carried out in the Niger Delta region of Nigeria by Adebayo et al., [7], Edo State with the foremost and biggest referral centre (University of Benin Teaching Hospital) was not captured.

The aim of this retrospective study is to present an audit of the types and pattern of major oral and maxillofacial surgeries (as well as their indications) carried out at the department of oral and maxillofacial surgery, University of Benin Teaching Hospital from January 2015 to December 2019 that would provide valuable information to develop a future strategic plan, and improve clinical care.

\section{METHODS}

This was a retrospective review of the hospital records (including theatre logbooks, theatre lists, case notes and admission notebooks in the wards) of all patients who had major surgery at the department of oral and maxillofacial surgery, University of Benin Teaching Hospital (UBTH), between January 2015 and December 2019. The data recorded were age, sex, occupation, date of admission, diagnosis, date of operation, indication for surgery, type of anaesthesia, and nature of surgery. Mortality and complications associated with the diseases and the surgery were however not included in our study.

\section{RESULTS}

Records of 242 patients who had 288 maxillofacial surgeries between 2015 and 2019 under general anesthesia formed the population for this study. The age range of cases was between 3 months to 85 years, with a median age of 23 years and mean age of $22.36 \pm 20.09$. Majority of the patients were between the ages of 3 months to 9years $(39.2 \%, \mathrm{n}=113)$ (Table1). There were $180(62.5 \%)$ males and $108(37.5 \%)$ females giving a male to female ratio of 1.6: 1 . On a year to year analysis, there was a steady increase in the turnout of patient of both gender with the males consistently higher in number (Figure-1).

Table-1: Age and gender distribution of cases done

\begin{tabular}{|l|l|l|l|}
\hline \multirow{2}{*}{ Age group } & Gender & \multicolumn{3}{|l|}{} \\
\cline { 2 - 4 } & Male $\mathbf{n}(\boldsymbol{\%})$ & Female n $(\boldsymbol{\%})$ & TOTAL $\mathbf{n}(\boldsymbol{\%})$ \\
\hline $0-9$ years & $79(27.4)$ & $34(11.8)$ & $113(39.2)$ \\
\hline $10-19$ years & $10(3.5)$ & $10(3.5)$ & $20(6.9)$ \\
\hline $20-29$ years & $28(9.7)$ & $27(9.4)$ & $55(19.1)$ \\
\hline $30-39$ years & $29(10.1)$ & $12(4.2)$ & $41(14.2)$ \\
\hline $40-49$ years & $20(6.9)$ & $10(3.5)$ & $30(10.4 \%)$ \\
\hline $50-59$ years & $5(1.7)$ & $7(2.4)$ & $12(4.2)$ \\
\hline $60-69$ years & $6(2.1)$ & $7(2.4)$ & $13(4.5)$ \\
\hline $70-79$ years & $2(0.7)$ & $0(0)$ & $2(0.7)$ \\
\hline $80-85$ years & $1(0.3)$ & $1(0.3)$ & $2(0.7)$ \\
\hline TOTAL & $180(62.5)$ & $108(37.5)$ & $288(100)$ \\
\hline
\end{tabular}


Okoro N. N \& Egbor P. E; Saudi J Oral Dent Res, Jan 2021; 6(1): 22-28

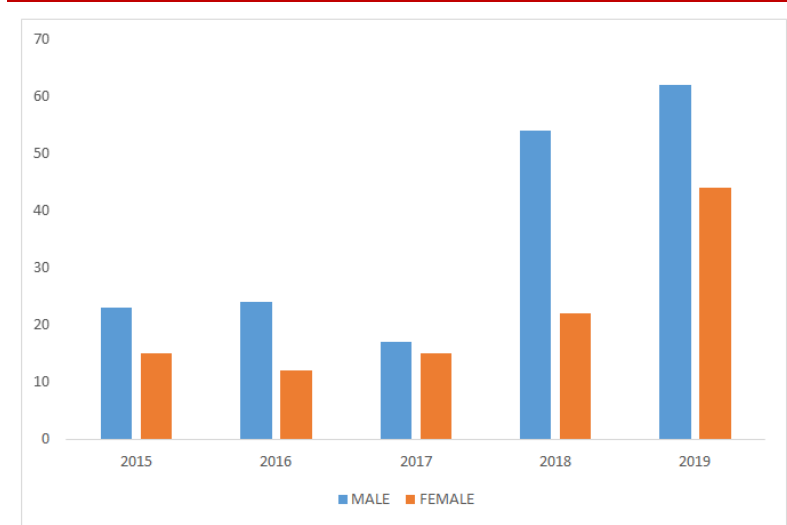

Fig-1: Gender distribution of maxillofacial surgical cases done in UBTH from year 2015 to 2019

The peak number of patients operated was in the year $2019(36.8 \%, \mathrm{n}=106)$, while the least numbers were observed in the year $2017(11.5 \%, \mathrm{n}=33)$. Congenital/developmental conditions accounted for the largest indication for surgery, accounting for 113
(39.4\%) of the cases, with cleft lip, and cleft palate the most common indications for surgery under the category and accounting for 107 (37.1) of the cases, followed by ameloblastoma 36 (12.5\%). The least indication for surgery was the cystic lesions which only accounted for 8 (2.8) of all cases seen (Table-2).

Benign tumour/lesions constituted majority of the tumour lesions seen $(24.4 \%, \mathrm{n}=70)$, while malignancies represented $29(10.1 \%)$. Traumatic conditions $(17.8 \%, \mathrm{n}=51)$ and other conditions $(4.5 \%$, $\mathrm{n}=13$ ) accounted for the remaining proportions. The most frequently histologically diagnosed benign tumour was ameloblastoma $(12.5 \%, \mathrm{n}=36)$ followed by the fibro-osseous lesions $(5.6 \%, \mathrm{n}=16)$ with the least being calcifying epithelial odontogenic tumour $(0.7 \%, \mathrm{n}=2)$ (Table-2). The most histologically diagnosed malignant tumour was squamous cell carcinoma $(6.9 \%, \mathrm{n}=20)$ followed by the sarcomas $(2.4 \%, \mathrm{n}=7)($ Figure-2).

Table-2: Indications for maxillofacial surgery and their year distribution

\begin{tabular}{|c|c|c|c|c|c|c|}
\hline & \multicolumn{6}{|c|}{ YEAR n $(\%)$} \\
\hline INDICATION FOR SURGERY & 2015 & 2016 & 2017 & 2018 & 2019 & TOTAL \\
\hline \multicolumn{7}{|l|}{ BENIGN LESIONS } \\
\hline Ameloblastoma & $6(2.1)$ & $5(1.7)$ & $3(1.0)$ & $10(3.5)$ & $12(4.2)$ & $36(12.5)$ \\
\hline Fibro-osseous lesions* & $0(0)$ & $1(0.3)$ & $2(0.7)$ & $4(1.4)$ & $9(3.1)$ & $16(5.6)$ \\
\hline Odontogenic/Desmoplastic fibroma & $1(0.3)$ & $0(0)$ & $0(0)$ & $0(0)$ & $2(0.7)$ & $3(1.0)$ \\
\hline Pleomorphic adenoma/salivary gland & $1(0.3)$ & $3(1.0)$ & $0(0)$ & $1(0.3)$ & $6(2.1)$ & $11(3.8)$ \\
\hline Calcifying epithelial odontogenic tumour & $0(0)$ & $1(0.3)$ & $0(0)$ & $0(0)$ & $1(0.3)$ & $2(0.7)$ \\
\hline SUB-TOTAL & $8(2.8)$ & $11(3.8)$ & $5(1.4)$ & $16(5.6)$ & $30(10.5)$ & $70(24.4)$ \\
\hline \multicolumn{7}{|l|}{ MALIGNANT LESIONS } \\
\hline Sarcomas & $0(0)$ & $1(0.3)$ & $2(0.7)$ & $2(0.7)$ & $2(0.7)$ & $7(2.4)$ \\
\hline Squamous cell carcinoma & $1(0.3)$ & $2(0.7)$ & $0(0)$ & $8(2.8)$ & $9(3.1)$ & $20(6.9)$ \\
\hline Non-Hodgkins Lymphoma & $2(0.7)$ & $0(0)$ & $0(0)$ & $0(0)$ & $0(0)$ & $2(0.7)$ \\
\hline SUB-TOTAL & $3(1.0)$ & $3(1.0)$ & $2(0.7)$ & $10(3.5)$ & $11(3.8)$ & $29(10.1)$ \\
\hline \multicolumn{7}{|l|}{ CONGENITAL ANOMALIES } \\
\hline Cleft Lip/Palate & $13(4.5)$ & $17(5.9)$ & $8(2.7)$ & $29(9.1)$ & $40(13.9)$ & $107(37.1)$ \\
\hline Others** & $1(0.3)$ & $0(0)$ & $0(0)$ & $1(0.3)$ & $1(0.3)$ & $3(1.0)$ \\
\hline SUB-TOTAL & $18(6.3)$ & $15(5.2)$ & $12(4.2)$ & $26(9.1)$ & $42(14.6)$ & $113(39.4)$ \\
\hline \multicolumn{7}{|l|}{ TRAUMATIC CONDITIONS } \\
\hline Mandibular fracture & $6(2.1)$ & $2(0.7)$ & $2(0.7)$ & $8(2.8)$ & $3(1.0)$ & $21(7.3)$ \\
\hline Zygomatic complex fracture & $2(0.7)$ & $0(0)$ & $3(1.0)$ & $2(0.7)$ & $5(1.7)$ & $12(4.2)$ \\
\hline Lefort/Maxillary/Orbital floor fracture & $1(0.3)$ & $0(0)$ & $2(0.7)$ & $2(0.7)$ & $3(1.0)$ & $8(2.8)$ \\
\hline TMJ Dislocation/Ankylosis & $1(0.3)$ & $0(0)$ & $2(0.7)$ & $1(0.3)$ & $0(0)$ & $4(1.4)$ \\
\hline Panfacial fracture & $0(0)$ & $0(0)$ & $1(0.3)$ & $1(0.3)$ & $3(1.0)$ & $5(1.7)$ \\
\hline Others $* * *$ & $0(0)$ & $0(0)$ & $3(1.0)$ & $3(1.0)$ & $4(1.4)$ & $10(3.5)$ \\
\hline SUB-TOTAL & $6(2.1)$ & $3(1.0)$ & $13(4.5)$ & $15(5.2)$ & $14(4.9)$ & $51(17.8)$ \\
\hline CYSTIC LESION & 2015 & 2016 & 2017 & 2018 & 2019 & TOTAL \\
\hline Odontogenic cysts & $2(0.7)$ & $1(0.3)$ & $1(0.3)$ & $0(0)$ & $1(0.3)$ & $5(1.7)$ \\
\hline Non-odontogenic cysts & $0(0)$ & $0(0)$ & $0(0)$ & $1(0.3)$ & $2(0.7)$ & $3(1.0)$ \\
\hline SUB-TOTAL & $2(0.7)$ & $1(0.3)$ & $1(0.3)$ & $1(0.3)$ & $3(1.0)$ & $8(2.8)$ \\
\hline OTHERS***** & $1(0.3)$ & $1(0.3)$ & $0(0)$ & $9(3.1)$ & $5(1.7)$ & $16(5.6)$ \\
\hline TOTAL & $38(13.2)$ & $34(11.8)$ & $33(11.5)$ & 77 (26.7) & $106(36.8)$ & $288(100)$ \\
\hline
\end{tabular}




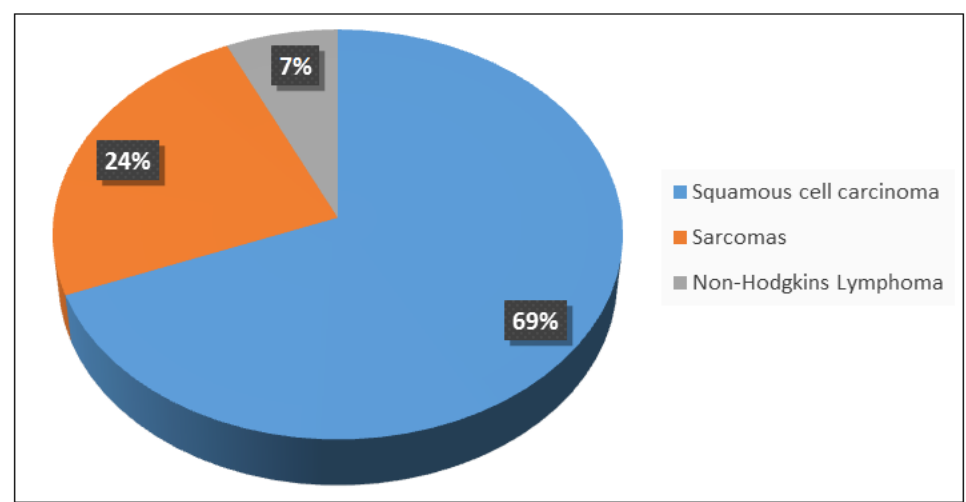

Fig-2: Distribution of malignant lesions seen from 2015 to 2019

The most commonly performed surgery was cleft lip/palate repair $(36.1 \%, \mathrm{n}=104)$, followed by mandibulectomy and reconstruction $(16.7 \%, \mathrm{n}=48)$. All patients who had mandibulectomy, also had immediate mandibular reconstruction done with titanium reconstruction plate and where disarticulation was done, a prosthetic condylar head inserted. Open
Reduction and Internal Fixation (ORIF) with titanium fracture and adaption plates, lag screws, and reconstruction plate were done in $45(15.6 \%)$ cases. Examination and suturing under General Anaesthesia (GA) and close reduction were infrequently done $(0.7 \%, \mathrm{n}=2$ each) (Table-3).

Table-3: Yearly distribution of maxillofacial surgical procedures

\begin{tabular}{|l|l|l|l|l|l|l|}
\hline \multicolumn{7}{|c|}{ YEAR n $(\%)$} \\
\hline NATURE OF SURGERY & 2015 & 2016 & 2017 & 2018 & 2019 & TOTAL \\
\hline Cleft lip/Palate repair & $13(4.5)$ & $17(5.9)$ & $8(2.7)$ & $25(8.7)$ & $37(12.8)$ & $104(36.1)$ \\
\hline Maxillectomy & $1(0.3)$ & $3(1.0)$ & $0(0)$ & $5(1.7)$ & $7(2.4)$ & $17(5.9)$ \\
\hline Mandibulectomy & $6(2.1)$ & $6(2.1)$ & $5(1.7)$ & $12(4.2)$ & $19(6.6)$ & $48(16.7)$ \\
\hline ORIF & $9(3.1)$ & $2(0.7)$ & $9(3.1)$ & $13(4.5)$ & $12(4.2)$ & $45(15.6)$ \\
\hline Close reduction and Fixation & $0(0)$ & $0(0)$ & $0(0)$ & $0(0)$ & $2(0.7)$ & $2(0.7)$ \\
\hline Incisional/ Excisional biopsy & $3(1.0)$ & $3(1.0)$ & $0(0)$ & $5(1.7)$ & $9(3.1)$ & $20(6.9)$ \\
\hline Wound exploration & $0(0)$ & $0(0)$ & $1(0.3)$ & $4(1.4)$ & $1(0.3)$ & $6(2.1)$ \\
\hline Suturing under GA & $0(0)$ & $0(0)$ & $0(0)$ & $0(0)$ & $2(0.7)$ & $2(0.7)$ \\
\hline Excision of lesions & $1(0.3)$ & $0(0)$ & $0(0)$ & $1(0.3)$ & $1(0.3)$ & $3(1.0)$ \\
\hline Neck dissection & $0(0)$ & $0(0)$ & $0(0)$ & $1(0.3)$ & $2(0.7)$ & $3(1.0)$ \\
\hline Facial / lip reconstruction & $1(0.3)$ & $0(0)$ & $1(0.3)$ & $0(0)$ & $5(1.7)$ & $7(2.4)$ \\
\hline Sequestrectomy & $1(0.3)$ & $0(0)$ & $0(0)$ & $3(1.0)$ & $0(0)$ & $4(1.4)$ \\
\hline Parotidectomy & $0(0)$ & $0(0)$ & $0(0)$ & $1(0.3)$ & $5(1.7)$ & $6(2.1)$ \\
\hline Enucleation & $2(0.7)$ & $1(0.3)$ & $0(0)$ & $2(0.7)$ & $0(0)$ & $5(1.7)$ \\
\hline Paring down & $0(0)$ & $1(0.3)$ & $2(0.7)$ & $0(0)$ & $2(0.7)$ & $5(1.7)$ \\
\hline Reconstruction plate removal & $0(0)$ & $1(0.3)$ & $0(0)$ & $2(0.7)$ & $2(0.7)$ & $5(1.7)$ \\
\hline TMJ reduction/Arthroplasty & $1(0.3)$ & $0(0)$ & $2(0.7)$ & $1(0.3)$ & $0(0)$ & $4(1.4)$ \\
\hline Partial glossectomy & $0(0)$ & $0(0)$ & $0(0)$ & $2(0.7)$ & $0(0)$ & $2(0.7)$ \\
\hline TOTAL & $38(13.2)$ & $34(11.8)$ & $33(11.5)$ & $77(26.7)$ & $106(36.8)$ & $288(100)$ \\
\hline & & & & & & \\
\hline
\end{tabular}

\section{DISCUSSION}

There was a steady increase in the number of major surgeries done year on year except for the year 2017 which was characterized by incessant disruption of industrial harmony between the hospital management and her staff. The significant increase in the number of surgeries seen in the year 2018 and 2019 may not be unrelated to the increased awareness of maxillofacial surgical specialty among the populace due to the frequent surgical outreaches carried out by volunteer maxillofacial surgeons. Furthermore, the improved surgical skills acquired by surgeons of the hospital that were sent for training have expanded the scope of surgery done by the department. It is therefore pertinent that continuous training of personnel will improve patient care.

More of the patients treated were males and this is consistent with findings from similar studies [610]. This could be attributable to the paternalistic tendencies in the health-seeking behavior in our environment $[11,12]$. Also, our findings may be a reflection of the fact that males have a higher prevalence of malignancy worldwide [13, 14], more are exposed to hazardous jobs and are involved in a lot of vehicular movement as the breadwinner increasing the chances of traumatic injuries. 
The age range of patients seen in this study is similar to reports in the literature $[15,16]$, with most of the patients in the first decades of life. This is however at variance with similar studies by Adebayo et al., [17] that reported the third decade as the modal age, and Ibinkunle et al., [18] that reported the 4th decade. This observed difference in age range could be ascribed to the fact that the commonest indication for surgery in our department was congenital deformities and the availability of the "Smile train" free surgical care for such conditions in the hospital. These anomalies are common in the first decade of life and parents are quite apprehensive and desirous of immediate repair of such defects.

Tumour and tumour-like lesions were the second commonest indication for major oral and maxillofacial surgery in our centre. The most occurring pathologic lesion in this study was ameloblastoma, an odontogenic tumour and this is in agreement with previous studies [10, 15]. However, Saleh et al., [19] in a study of histologically diagnosed oral and maxillofacial lesions reported odontogenic keratocyst to be the commonest benign odontogenic tumour.

Studies [16, 18, 20] have reported squamous cell carcinoma to be the predominantly occurring malignancy of the orofacial region and our finding was in consonance. The increasing prevalence of oral squamous cell carcinoma may be attributable to the reported rise of the major predisposing factors such as high-risk strains of human papillomavirus, increasing intakes of alcohol and tobacco smoking and precancerous lesions such as hyperplastic candidiasis, erythroplakia [21, 22].

Contrary to previous reports $[15,16]$ of traumatic injuries been the commonest indication for maxillofacial surgeries, our study found trauma to be the third commonest indication for surgery following congenital defects and tumours. Our findings could be due to the imposed ban on the use of motorcycles in the city metropolis by the government and the strict enforcement of the speed limit and the use of crash helmets for cyclists. In our study, the use of biocompactible titanium mini and microplates has remained the mainstay of fracture reduction and immobilization except for very few cases where the inability of patients to pay for miniplates resulted in the use of inter-maxillary fixation.

Mandibular fractures were the most commonly seen of the types of maxillofacial fractures. This is in agreement with various studies in the literature [23-25]. Obuekwe et al., [23] and Oginni et al., [24] reported the mandible as the most often fractured facial bone. Obimakinde et al., [25] reported that mandible was the most prominent skeletal injury and the body of the mandible was the most common site of fracture. However, this is at variance with other studies, where maxillary fractures were more frequently diagnosed [26, 27]. Hwang et al., [28] reported the nasal bone fracture as the most frequently encountered maxillofacial injuries. This is due to the more prominent nature of the nasal bones among the Caucasians compared to the blacks that have the mandible as the more prominent bone [29]. Maxillofacial injuries represent a major contributory indication for surgery in the oral and maxillofacial specialty in many countries with its attendant socioeconomic burden on the affected individuals and family caregivers [7, 30].

A wide range of surgical procedures was carried within the period under review with observed successes and challenges. Repair of congenital defects mainly cleft lip and palate were the most surgeries carried out. While various techniques of repair of cleft lip and cleft palate have been advocated in the literature, Millard's technique (unilateral cleft lip), Clayton de Hoan (bilateral cleft lip), and the V-Y technique (cleft palate) were most used by the surgeons in our institution. Several reasons could be adduced for the large number of cleft lip and palate surgeries. First, our hospital is reputed in the South-South region of Nigeria as a centre of excellence in the care of cleft deformities with her functional multidisciplinary cleft team. Second, there is a growing awareness among the populace of this condition and the possibility of repair necessitated by the frequent public enlightenment carried out by the Community Dentistry department of the hospital. Third, is the very significant role of the "Smile train" project in our hospital that allows for these patients to receive free surgical and supportive care that were hitherto the source of hindrance to receiving treatment. The impact of the Smile train project is well documented in the literature [31].

Mandibulectomies were the most common ablative surgeries in this audit. This may be because most of the tumours were ameloblastoma and squamous cell carcinoma that has a high predilection for the mandible and the mandibular mucosa respectively [32]. Most of the patients who had mandibulectomy had immediate mandibular reconstruction done using the titanium reconstruction plates and were indicated also had condylar prostheses. A few cases of bone grafting using iliac crest done where the defect was less than $10 \mathrm{~cm}$ were done. Soft tissue losses that could not be closed primarily were closed using either pedicled local or distant flaps.

The increased dependence on reconstruction plates for the mandibular defects in this study brings to the fore the need for the department to embrace the use of microvascular graft and flaps. These techniques have revolutionized reconstructive surgery because it provides adequate vascular supply, provides predominantly compact bone with sufficient rigidity, good contour and resistance to infections $[33,34]$. Also, 
Okoro N. N \& Egbor P. E; Saudi J Oral Dent Res, Jan 2021; 6(1): 22-28

they are suitable for long span defects, which are commonly encountered following tumour ablation in our clime owing to the late presentation of patients [35]. There is, therefore, the urgent need by the hospital management for concerted manpower training and provision of necessary facilities that will help in improving patient management and outcomes.,

Maxillectomy is also a common tumour ablative technique done in our hospital. The major indication for maxillectomy was antral carcinoma. Other indications for maxillectomy in our study were osteosarcoma, adenomatoid odontogenic tumour, and maxillary ameloblastoma. The defects created were all reconstructed with obturators

A few of combined maxillo-mandibular resections were carried out in this study. These resulted mainly from the contiguous spread of advanced lesions from one jaw to another. The majority of cases who had mandibular resection on account of squamous cell carcinoma had elective neck dissection. This is consistent with literature that advocates elective neck dissection for malignancies of the head and neck region [36, 37].

Salivary gland surgeries were relatively few. However, it is important to note that in our hospital, salivary gland surgeries are also performed by the Otorhinolaryngologist and the general surgeons. Thus, our report does not represent the frequency of salivary gland surgeries in the hospital. Parotidectomies accounted for the majority of the salivary gland surgeries with pleomorphic adenoma being the major indication for surgical intervention. This is in agreement with studies by Ajayi et al., [38] and Okoturo et al., [39] that stated that pleomorphic adenoma was the commonest salivary gland tumour. Furthermore, OluEddo et al., [40] reported that the parotid gland is the most common site for salivary gland cancers. Submandibular gland excisions following protracted submandibular sialadenitis were also performed.

\section{CONCLUSION}

The field of oral and maxillofacial surgery in the last three decades has come to be a well-established surgical specialty with commendable strides. The audit reveals an array of procedures done in the hospital. However, there is an urgent need to invest in manpower training and facilities to enable microvascular surgeries to be carried out. This will in no small measure improve the surgical outcome as well as improve patient's quality of life.

\section{REFERENCES}

1. Akinmoladum, V. I., Gbolaham, O. O., Akaditi, O. A., \& Akinyamoju, C. A. (2015). Evaluation of the scope and practice of oral and maxillofacial surgery in Nigeria. Nigerian journal of clinical practice, 18(2), 282-286.

2. Hunter, M. J., Rubeiz, T., \& Rose, L. (1996). Recognition of the scope of oral and maxillofacial surgery by the public and health care professionals. Journal of oral and maxillofacial surgery, 54(10), 1227-1232.

3. National Institute for Clinical Excellence (Great Britain). (2002). Principles for best practice in clinical audit. Radcliffe publishing.

4. Yorston, D., \& Wormald, R. (2010). Clinical auditing to improve patient outcomes. Community eye health, 23(74):48.

5. Upile, T., Jerjes, W., Sipaul, F., El Maaytah, M., Nouraei, S. A. R., Singh, S., ... \& Wright, A. (2007). The role of surgical audit in improving patient management; nasal haemorrhage: an audit study. BMC surgery, 7(1), 19.

6. Ibikunle, A. A., Taiwo, A. O., \& Braimah, R. O. (2018). A 5-year audit of major maxillofacial surgeries at Usmanu Danfodiyo university teaching hospital, Nigeria. BMC health services research, 18(1), 416.

7. Adebayo, E. T., Ajike, S. O., \& Abite, M. G. (2008). Audit of oral and maxillofacial surgical conditions seen at Port Harcourt, Nigeria. Annals of African medicine, 7(1), 29.

8. Ajike, S. O., Arotiba, J. T., Adebola, R. A., Ladeinde, A., \& Amole, I. O. (2004). Spectrum of oral and maxillofacial surgical procedures in Kano, Nigeria. West Indies Medical Journal, 53(suppl 6):9-12.

9. Gbotolorun, O. M., Emeka, C. I., Effiom, O., Adewole, R. A., \& Ayodele, A. S. (2016). An audit of malignant oro-facial tumors presenting at a tertiary hospital in Lagos. Annals of medical and health sciences research, 6(2), 133-136.

10. Islam, M. A., Haider, I. A., Uzzaman, M. H., Tymur, F. R., \& Ali, M. S. (2016). One year audit of in patient Department of Oral and Maxillofacial Surgery, Dhaka dental college hospital. Journal of maxillofacial and oral surgery, 15(2), 229-235.

11. Makama, G. A. (2013). Patriarchy and gender inequality in Nigeria: the way forward. European Scientific Journal, 9:17.

12. Oluyemo, C. A., \& Ola, T. (2014). The rights of Nigerian women in a patriarchal society: implication for development. Journal of Research in Gender Studies, 4(2), 373.

13. Bray, F., Ferlay, J., Soerjomataram, I., Siegel, R. L., Torre, L. A., \& Jemal, A. (2018). Global cancer statistics 2018: GLOBOCAN estimates of incidence and mortality worldwide for 36 cancers in 185 countries. CA: a cancer journal for clinicians, 68(6), 394-424.

14. Torre, L. A., Bray, F., Center, M. M., Ferlay J., Ward, E., \& Forman, D. (2015). Global cancer statistics 2015. CA: Cancer Journal for Clinicians, 65(2):87-108. 
Okoro N. N \& Egbor P. E; Saudi J Oral Dent Res, Jan 2021; 6(1): 22-28

15. Rehmann, B., \& Din, Q. U. (2009). Two-year audit of Maxillofacial Surgery department at Khyber college of Dentistry. Peshwer. Pakistan Oral Dental Journal, 29(1):13-18.

16. Islam, M. A., Haider, I. A., Uzzaman, M. H., Tymur, F. R., \& Ali, M. S. (2016). One year audit of in patient Department of Oral and Maxillofacial Surgery, Dhaka dental college hospital. Journal of maxillofacial and oral surgery, 15(2), 229-235.

17. Adebayo, E. T. (2004). Maxillofacial fractures in Port Harcourt, Nigeria-A short report. African Journal of Trauma, 2, 85-87.

18. Ibikunle, A. A., Taiwo, A. O., \& Braimah, R. O. (2016). Oral and maxillofacial malignancies: An analysis of 77 cases seen at an academic medical hospital. Journal of Orofacial Sciences, 8(2), 80.

19. Saleh, S. M., Idris, A. M., Vani, N. V., Tubaigy, F. M., Alharbi, F. A., Sharwani, A. A., ... \& Warnakulasuriya, S. (2017). Retrospective analysis of biopsied oral and maxillofacial lesions in south-western Saudi Arabia. Saudi medical journal, 38(4), 405.

20. Vigneswaran, N., \& Williams, M. D. (2014). Epidermiological trends in Head and Neck cancer and aids in diagnosis. Oral Maxillofacial clinic of North America, 12(2):123.

21. Conway, D. I., Purkayastha, M., \& Chestnutt, I. G. (2018). The changing epidemiology of oral cancer: definitions, trends, and risk factors. British dental journal, 225(9), 867-873.

22. Ghantous, Y., \& Abu, I. E. (2017). Global incidence and risk factors of oral cancer. Harefuah, 156(10), 645-649.

23. Obuekwe, O. N., Ojo, M. A., Akpata, O., \& Etetafia, M. (2003). Maxillofacial trauma due to road traffic accidents in Benin City, Nigeria: a prospective study. Annals of African Medicine, 2(2), 58-63.

24. Oginni, F. O., Oladejo, T., Alake, D. P., Oguntoba, J. O., \& Adebayo, O. F. (2016). Facial bone fractures in Ile-Ife, Nigeria: An update on pattern of presentation and care. Journal of maxillofacial and oral surgery, 15(2), 184-190.

25. Obimakinde, O. S., Ogundipe, K. O., Rabiu, T. B., \& Okoje, V. N. (2017). Maxillofacial fractures in a budding teaching hospital: a study of pattern of presentation and care. The Pan African Medical Journal, 26:218.

26. Hameed, I., Khan, M. I., Khan, S., \& Khan, S. (2014). An Audit of 120 Cases Of Simple Nasal Bone Fracture. Gomal Journal of Medical Sciences, 12(1).

27. Gassner, R., Tuli, T., Hächl, O., Rudisch, A., \& Ulmer, H. (2003). Cranio-maxillofacial trauma: a 10 year review of 9543 cases with 21067 injuries. Journal of cranio-maxillofacial surgery, 31(1), 51-61.

28. Hwang, K., \& You, S. H. (2010). Analysis of facial bone fractures: An eleven-year study of
2094 patients. Indian Journal of Plastic Surgery, 43(1):42.

29. Vyas, A., Mazumdar, U., Khan, F., Mehra, M., Parihar, L., \& Purohit, C. (2014). A study of mandibular fractures over a 5-year period of time: A retrospective study. Contemporary clinical dentistry, 5(4), 452.

30. Olusanya, A. A., Adeleye, A. O., Aladelusi, T. O., \& Fasola, A. O. (2015). Updates on the epidemiology and pattern of traumatic maxillofacial injuries in a nigerian university teaching hospital: a 12-month prospective cohort in-hospital outcome study. Craniomaxillofacial trauma \& reconstruction, 8(01), 50-58.

31. Hamze, H., Mengiste, A., \& Carter, J. (2017). The impact and cost-effectiveness of the Amref Health Africa-Smile Train Cleft Lip and Palate Surgical Repair Programme in Eastern and Central Africa. Pan African Medical Journal, 28(1):35.

32. Lawal, A. O., Adisa, A. O., \& Effiom, O. A. (2017). A review of 640 Oral squamous cell carcinoma cases in Nigeria. Journal of clinical and experimental dentistry, 9(6), e767-771.

33. Obiechina, A. E., Ogunlade, S. O., Fasola, A. O., \& Arotiba, J. T. (2003). Mandibular segmental resection with iliac crest. West Africa Journal of Medicine, 22(1):46-49.

34. Akadiri, O. A. (2012). Evolution and trends in reconstructive facial surgery: An Update. Journal of Maxillofacial and Oral Surgery, 11(4):466-472.

35. Ndukwe, K. C., Aregbesola, S. B., Ikem, I. C., Ugboko, V. I., Adebiyi, K. E., Fatusi, O. A., ... \& Braimah, R. O. (2014). Reconstruction of mandibular defects using nonvascularized autogenous bone graft in nigerians. Nigerian Journal of Surgery, 20(2), 87-91.

36. de Bree, R., Takes, R. P., Shah, J. P., Hamoir, M., Kowalski, L. P., Robbins, K. T., ... \& Shaha, A. R. (2019). Elective neck dissection in oral squamous cell carcinoma: Past, present and future. Oral oncology, 90, 87-93.

37. Kowalski, L. P., \& Sanabria, A. (2007). Elective neck dissection in oral carcinoma: a critical review of the evidence. Acta otorhinolaryngologica italica, 27(3), 113-117.

38. Ajayi, O. F., Olawuyi, A., Anunobi, C. C., Bamgbose, B. O., \& Adeyemo, W. L. (2017). Clinicopathologic Audit of Salivary Gland Lesions. Nigeria Journal of Basic Science, 14:101104.

39. Okoturo, E., \& Osasuyi, A. (2016). Clinical outcome of parotidectomy with reconstruction: Experience of a regional head and neck cancer unit. Nigerian Journal of Surgery, 22(1), 26-31.

40. Noma, O. E. A., \& Obiora, U. J. (2015). Salivary gland cancer in Benin City, Nigeria: A pathologic study. African Journal of Medical and Health Sciences, 14(1), 47. 